ayailable from the Bloomfield $H$. Moore fund, which, through the recent gift of Mrs. Clara Bloomfield Moore, has been almost doubled.

A like expression of grateful acknowledgment is due, and is hereby tendered, to the family and executors of the late George S. Pepper.

By order of the board.

JOSEPH M. WrLson, President.

\title{
ABSTRACT FROM THE ANNUAL REPORT OF THE COMMITTEE
} ON LIBRARY.

(For the year 1890 .)

During the year the following additions were made to the library :

Volumes bound, . . . . . . . . . . . r,080

Volumes unbound, . . . . . . . . . . . 630

Pamphlets, .............. . . 1,350

Total, . . . . . . . . . . . . 3,060

Maps and charts, . . . . . . . . . . . . . 179

Photographs and lithographs, ......... II

Newspaper clippings, . . . . . . . . . . . . . . 4

Circulars, ................. 45

Total additions of all kinds, . . . . . . . . . . 3,299

Total number of volumes in the library at the close of

1889. . . . . . . . . . . 33,305

Additions, bound and unbound volumes, $1890, \ldots$ 1,710

Total number of volumes in the library at close of $1890, \ldots \ldots \ldots \ldots \ldots$. . . . . . . . 35,015

Pamphlets.-Total number in the library, December $3 \mathbf{x}$,

$1889, \ldots \ldots \ldots \ldots . \ldots \ldots 19,622$

Add those received in $1890, \ldots \ldots . . . . .1,350$

Total, . . . . . . . . . . . . . . 20,972

Total number of maps and charts at the close of $1890, \ldots \ldots 1,962$

Designs and drawings, . . . . . . . . . . 603

Photographs and lithographs, . . . . . . . . . I,050

Newspaper clippings, . . . . . . . . . . . . . n6

Circulars, . . . . . . . . . . . . . . $9^{8}$

Manuscripts, .................. 2I

Duplicates.-The number of duplicates on hand at the close of 1890 : Volumes, 2.762; pamphlets, 5,857; charts, 169 ; periodicals; 8,022.

Moore fund.-During the year $\mathrm{r} 32$ volumes, 126 unbound volumes and 4 pamphlets were purchased with this fund. Six volumes were rebound and one was repaired. 
Public use of the library.-89I receipts were filed by non-members during the year, consulting 2,472 volumes of patents, 534 numbers of the official gazette, 942 volumes and 43 pamphlets from the other departments of the library,

Circulation.-2,037 volumes were issued to memhers for home use, an increase of 348 over 1889 , and 788 over 1888.

Exchanges.-The number during 1890 amounted to 380 , an increase of 4 compared with the previous year.

By order of the Committee on Library,

WM. H. WAHL, Secretary.

\section{ANNUAL REPORT OF THE COMMITTEE ON SCIENCE AND FHE ARTS.}

The chairman of the Committee on Science and the Arts respectfully makes the following report of the work of the committee for the year 1890 :

The total number of new applications received during the year was sixtytwo, of which fify-five were approved for investigation, six rejected by the preliminary committee and one withdrawn. Thirty-four reports have been acted upon during the year and forty are still pending.

In four cases the award of the Elliott Cresson medal was recommended; in eleven, the John Scott legacy medal and premium, and in two, certificates of merit, and in the reports completed and now pending there are two awards of the Elliott Cresson medal and three of the John Scott legacy medal and premium.

Protests have been received to three of the awards of the committee, two of which, after investigation, were not sustained, and the third was withdrawn.

The foundation of the Fdward Longstreth medal of merit, through the liberality of Mr. Fdward Longstreth, will add greatly to the resources of the committee, in enabling it to make an award in many deserving cases which the regulations governing the awards, heretofore in the control of the committee, prohitited.

The committee deemed it best to andend its by-laws by inserting a provision forbidding members of the committee to receive awards except in cases where the institute directed that the investigation should be made.

The committee has undertaken to investigate the subject of hot.water boilers for heating purposes, and a sub-committee is now at work preparing a code for testing such boilers.

The index of the work of the committee from 1834 to 1890 has been completed and published, and the reports are now available for reference. The thanks of the committee are due to Mr. S. Lloyd Wiegand, one of its members, for the interest and labor he has expended in the execution of this work.

Respectfully submitted,

H. W. SPANGLLK,

Ch. Com. Sci. and Ants. 